Issues in theory and methods of teaching foreign languages

Проблеми теорії і методики навчання іноземних мов

Удк 81-119

\title{
PREPARATORY STAGES OF TERMINOLOGICAL WORK OBSERVING AUTOMATION CONCEPTS
}

\author{
K.H.YAKUSHKO, PhD in Pedagogy, senior lecturer, \\ National University of Life and Environmental Sciences of Ukraine \\ E-mail:vukladach@ukr.net \\ ORCID: 0000-0001-6977-8441
}

\begin{abstract}
The article deals with the description of the practice to implement linguistic studies on the practical lessons of the professionally oriented English. The main conclusions: the development of interdisciplinary relations of philology with automation is an important prerequisite to develop professional mobility of each future specialist in automation basing upon a certain algorithm, the first stages of which (preliminary detection of unfamiliar professional notions texts, inventory of existing lexical units being associated with the specification of the terms of the exact field of knowledge and the identification of the most commonly professional terms-phrases) conclude the background for the more responsible communicative-oriented stages of working with the terminology system. The prospect of research is to describe such further stages on the practical lessons of the professionally oriented English as the narrowing the circle for practical use at the choice of students; finding the most successful phrases after familiarization with auxiliary communicative tables to represent different communicative intentions; consolidation of the received linguistic knowledge in business games and dialogues-duels.

Keywords: automatic terms, algorithm of terminological work, practical linguistic studies, the previous terminological work stages, professionally oriented English, future specialist in automation
\end{abstract}

Introduction. The development of linguistics as a science deals with the attempts to develop the new approaches to the humanities in general and engineer's terminological work to develop interdisciplinary relations.

Some modern linguists regard the multisectoral prevailing terminological systems as the multifaceted, heterogeneous, non-uniform and requiring periodic review as well as the adjustment of methodological foundations, wordformation tools and structure of existing terms [1]. Besides, some linguistic investigations deal with the practical orientation of linguistic studies, for example, through the analysis of specific

Methods. To achieve above named purpose it is in need to apply such terminology systems like the scientific and technical automatic terminology due to the observing either lexical, structural features of automatic terms or every terminological analysis practical orientation to regard the terminology of the text as the basis for the future engineers' foreign language communication culture formation too [2], [3], [4], [5]. But the linguistic science is still short of description of the practical algorithms to deal with real thematic terminological work.

The purpose of article is to describe the experience to use the previous stages of the automatic terms terminological work algorithm basing upon the material of the corresponding manual [6].

methods of empirical research as observation, comparison, monitoring and

(C) K.H.Yakushko

«International journal of philology» | «Міжнародний філологічний часопис» Vol. 10, № 1, 2019 
such methods of theoretical research as analysis, ascension from abstract definitions to the concrete ones as well as axiomatic method.

Results. It is periodically in need to involve practical linguistic studies during the professionally oriented English language lessons, for example, while working with automatic terminology basing upon the following algorithm: 1) the preliminary detection of unfamiliar concepts of professional texts; 2) inventory of existing lexical units being related to the specification of the terms concerning the particular field of knowledge; 3) identification of some stable professional terms and phrases being the most commonly used in practice ; 4) narrowing the circle for practical use basing upon the students 'choice; 5) finding the most successful phrases after familiarization with the auxiliary communicative tables concerning the expression of the request, consent, disagreement, incentive to work together, discussion of the results of the joint activity, commentary, etc.; 6) consolidation of the received linguistic knowledge in business games and dialogues-duels.

The first stage of the preliminary detection of professional texts unfamiliar concepts basing upon the module «Automation. Robotic Systems. Computer and Programming. Modeling of Biotechnical Objects» material is to determine the unknown lexical units in the alphabetical order. A group of lexical units concerning such letters as «A», «B», «C» та «D» may be represented in a following way: «actuator - виконавчий (пусковий) механізм; ACK (ACKnowledgement) повідомлення про успішний прийом даних; acquisition - придбання; according to the changes of its environment - враховуючи зміни зовнішніх умов; to achieve a task успішно виконати завдання; $A D$ (Automatic Design) - автоматичне проектування; ACCS (Adaptive Control and Control Systems) - адаптивне керування та системи контролю; adder блок розрахунку; advanced - передовий; agricultural - сільськогосподарський; animal husbandry - тваринництво; amount of infrared light - величина інфрачервоного випромінювання; APE (Automatic Processing Experiments) експерименти на основі автоматичної обробки данних; APD (Automatic Processing Data) - автоматична обробка показників; applied - застосований; Approaches of Selective Fertilizer Control - підходи до вибіркового контролю за станом добрива; artificial intelligence штучний інтелект; AR (Automation Research) - дослідження у сфрері автоматики; ASP (Application Software Packages) - застосування пакетів (програм) програмного забезпечення; Automatic Control Theory - теорія автоматичного управління; automata автомати; Automation System Design розробка автоматичних систем; applying- застосовуючи; awarded нагороджений; auto-regulated bioautomatic control ventilation system авторегульована біоавтоматична система контролю вентиляції; behaviorbased control architecture проектування підконтрольних дій; BIOS (Basic Input/Output System) - базова система вводу-виведення показників, capability to observe the environment здатність сканування довкілля; cattle худоба; cattle barns - стійла для худоби; calculations - підрахунки; connecting link - зв'язуюча ланка; certain sequence of operations - певна послідовність дій; circuit board - плата (тех.); closed-loop control - контроль замкненості; complete location information - повна інформація про розташування; complexity of the operations- комплекс дій; CAD (Computer-Aided Design) - проектування на основі комп'ютерних технологій; Computer Hardware and Computational 
Theory - комп'ютерна апаратура та теорія розрахунків; conversionперетворення, dairy farm - молочна ферма; department - відділення, кафредра; to detect the ripeness of fruit визначити стиглість плода; to determine the location - визначити параметри розташування; developed - вдосконалений, розвинутий». The list of the previously detected unknown concepts representing the letters «E», «F», «H» and «l» may be shown in the following way: «electronic circuits - електронні схеми; energy saving - енергозбереження; energy saving irradiation technologies - енергозберігаючі технології опромінення; equipment обладнання; equations - рівняння; exhaust ventilation control - контроль вихлопної вентиляції; enterprises підприємства; extremely high rates винятково високі показники; feedback віддача(тех.); fertilizer use modeling моделювання внесення добрив; filtering of sensor noise - відфільтровування шумів датчика; flexible control - гнучке управління; FTP (File Transfer Protocol) - протокол передачі фрайлів; hardware - апаратура (зовнішне налаштування); high precision movement interaction - висока точність взаємодії рухомих об'єктів; host computer вузловий комп'ютер; gas installation газова установка; grain dryer зерносушарка; greenhouse - теплиця; Identification and Process Simulation визначення та імітування процесів; implemented - запроваджений; imprecise - неточно; in order to solve the program - 3 метою вирішення завдань програмування; industrial machinery промислове обладнання; infrared sensors - датчики інфррачервоного випромінювання; initiate button - кнопка запуску; instantaneous reaction миттєва реакція; intricate network складна мережа; introduced запроваджений; intelligent control systems - системи управління 3 штучним інтелектом; integration of sensors - інтеграція датчиків; interrelated - взаємопов'язаний; interdependent components - взаємозалежні складові; invention - винахід; to involve number of subtasks - залучити низку підзадач». The list of the previously detected unknown concepts representing the letters «M», «N», «O», «P» and «R» may be shown in the following way: «majority of manufacturing techniques більшість виробничих технологій; manuals - посібники; to measure виміряти; modeling nurseries моделювання теплиць-розсадників; modeling the impact of diseases and pests - моделювання впливу захворювань та шкідників; models of animal breeding - моделі тваринництва; models of plant growing - моделі рослинництва; moisture of nutritious substance - волога у поживній речовині; NN (Neural Networks) - нейронні мережі; number of subtasks - набір підзадач; numerous instructions compilation численні інструкції щодо збірки (комплектування); nutrient absorbing model - модель поглинання поживних речовин; to occur - спричинити; on a large scale - у великому масштабі; to order - запустити в дію; overall task сукупне завдання; output parameters вихідні параметри; participating беручи участь; performed in sequence представлений у послідовності; pigsty свинарник; power and energy account величина енергії і потужності; plants 1.рослини 2. заводи; poultry - домашня птиця; proximity sensors - датчики близькості розташування об'єктів; to provide - забезпечити; production виробництво; productivity ефективність; Programming and Algorithmic Languages - програмування та мови (знакові системи) алгоритмів; RAM (Random-Access Memory) оперативна пам'ять; reducing - 
знижуючи; Real-Time Systems Programming - програмування алгоритму дій в реальному часі; releasing - вивільняючи, полегшуючи; to relieve- полегшувати; reproduction of biotechnical objects - відновлення біотехнічних об'єктів; reliable control надійний контроль; renewable energy use- використання відновних джерел енергії; ROM (Read Only Memory) постійна пам'ять; replacing - замінюючи; research directions - напрями дослідження; research directionдослідницькі напрями;reset button кнопка скидання, перезапуску». The following lexical units are assigned to the category of the letters «S», «T», «U», «V》 and «W»: «selection actuators application - підбір способів застосування виконавчих механізмів; screen - екран; simple instructions execution - виконання простих інструкцій; to solve - вирішити; to subdivide - розділити; sequence sensing - послідовне розпізнання; set of different sensors - набір різних датчиків; software - програмне забезпечення; step-by-step acting - покрокова дія (виконання алгоритму); significantly значно; simulating - імітація; subtraction - віднімання; to suppose передбачити;task-specific motion path planning - планування контуру руху відповідно до заданого завдання; Technological Process Simulation моделювання технологічного процесу; Theoretical Fundamentals of Automation теоретичні основи автоматики; transmission and use of energy передача та використання енергії; triangulation - трьохвимірна площина; Typical Production Facilities and Production Processes - типові виробничі потужності та виробничі процеси; ultrasonic sensors - ультразвукові датчики; unreliable -ненадійний; up-todate- новітній;valves - клапани; visual surveillance and control program візуальний нагляд та контроль програми within intelligent environment у межах умов впливу штучного інтелекту; without human input - без втручання людини».

The second stage of the work with the automatic terms is to detect lexical units being associated with the specification of the terms of automation itself in a following way: «actuator - виконавчий (пусковий) механізм; AD (Automatic Design) - автоматичне проектування; ACCS (Adaptive Control and Control Systems) - адаптивне керування та системи контролю; АРE (Automatic Processing Experiments) - експерименти на основі автоматичної обробки данних; APD (Automatic Processing Data) автоматична обробка данних; artificial intelligence - штучний інтелект; AR (Automation Research) - дослідження у сорері автоматики; ASP (Application Software Packages) - застосування пакетів (програм) програмного забезпечення; Automatic Control Theory - теорія автоматичного управління; automata - автомати; Automation System Design - розробка автоматичних систем; regulated bioautomatic control ventilation system - авторегульована біоавтоматична система контролю вентиляції; behavior-based control architecture - проектування підконтрольних дій; capability to observe the environment - здатність сканування довкілля; CAD (Computer-Aided Design) - проектування на основі комп'ютерних технологій; Computer Hardware and Computational Theory - комп'ютерна апаратура та теорія розрахунків; electronic circuits - електронні схеми; feedback - віддача(тех.); fertilizer use modeling - моделювання внесення добрив; filtering of sensor noise відфільтровування шумів датчика; (File Transfer Protocol) - протокол передачі фрайлів; hardware - апаратура (зовнішнє налаштування); high precision movement interaction - висока точність взаємодії

(C) K.H.Yakushko

«International journal of philology» | «Міжнародний філологічний часопис» Vol. 10, № 1, 2019 
рухомих об'єктів; Identification and Process Simulation - визначення та імітування infrared sensors - датчики інфрачервоного випромінювання; intelligent control systems - системи управління 3 штучним інтелектом; integration of sensors - інтеграція датчиків;; modeling nurseries моделювання теплиць-розсадників; modeling the impact of diseases and pests - моделювання впливу захворювань та шкідників; models of animal breeding - моделі тваринництва; models of plant growing - моделі рослинництва; NN (Neural Networks) нейронні мережі; proximity sensors датчики близькості розташування об'єктів;; Real-Time Systems Programming - програмування алгоритму дій в реальному часі; sequence sensing - послідовне розпізнання; set of different sensors набір різних датчиків; software програмне забезпечення; step-by-step acting - покрокова дія (виконання алгоритму); task-specific motion path planning - планування контуру руху відповідно до заданого завдання; Technological Process Simulation моделювання технологічного процесу; Theoretical Fundamentals of Automation теоретичні основи автоматики; ultrasonic sensors - ультразвукові датчики.

The second stage of the work with the automatic terms deals with reduction and definition of the most commonly used professional terms and terminological compounds being represented in a following way: «actuator - виконавчий (пусковий) механізм; AD (Automatic Design) - автоматичне проектування; ACCS (Adaptive Control and Control Systems) - адаптивне керування та системи контролю; APE (Automatic Processing Experiments) - експерименти на основі автоматичної обробки данних; APD (Automatic Processing Data) - автоматична обробка данних; artificial intelligence - штучний інтелект; AR (Automation Research) - дослідження у сорері автоматики; ASP (Application Software Packages) - застосування пакетів (програм) програмного забезпечення; automata - автомати; Automation System Design - розробка автоматичних систем; behavior-based control architecture - проектування підконтрольних дій; capability to observe the environment - здатність сканування довкілля; CAD (Computer-Aided Design) - проектування на основі комп'ютерних технологій; electronic circuits електронні схеми; hardware апаратура; sensors - датчики; modeling - моделювання; Real-Time Systems Programming - програмування алгоритму дій в реальному часі; sensing -розпізнання; set of sensors - набір датчиків; software - програмне забезпечення; step-by-step acting покрокова дія (виконання алгоритму) Technological Process Simulation моделювання технологічного процесу.

Conclusion and research prospects. Thus, the development of interdisciplinary relations of philology with automation is an important prerequisite to develop professional mobility of each future specialist in automation basing upon a certain algorithm, the first stages of which (preliminary detection of unfamiliar professional notions texts, inventory of existing lexical units being associated with the specification of the terms of the exact field of knowledge and the identification of the most commonly professional termsphrases) conclude the background for the more responsible communicative-oriented stages of working with the terminology system. The prospect of the study is to describe such further stages to work with the terminology units on the practical lessons of the professionally oriented English language as the narrowing the circle for practical use at the choice of 
students; finding the most successful e phrases after familiarization with auxiliary communicative tables to represent different communicative intentions; consolidation of the received linguistic knowledge in business games and dialogues-duels.

\section{Список використаних джерел}

1.Шинкарук В. Д., Харченко С. В. Методика лінгвістичного описування назв зелених насаджень.Науковий вісник Національного університету біоресурсів і природокористування України. Серія: Філологічні науки. Київ: Міленіум, 2017. Вип.276. С.71-78.

2. Якушко К. Г. Роль терміносистеми тексту «Vehicle Parts» у формуванні іншомовної культури спілкування майбутнього агроінженера. Науковий вісник Національного університету біоресурсів і природокористування України. Серія:Філологічні науки. Київ: Міленіум, 2017. Вип.276. С. 86-94

3. Якушко К. Г. Термінологічний аналіз іншомовного текстового матеріалу першого модуля із сфери автоматики. Молодий вчений. №8(60). 2018. C.111-116.

4. Якушко К. Г. Лексично-структурні особливості іншомовного текстового матеріалу другого модуля із сфери автоматики.Молодий вчений. № 9(61). 2018. С.128-131.

5.Якушко К. Г.,Березова Л. В. Практична спрямованість термінологічного аналізу поняття «switch» на занятті 3 англійської мови за професійним спрямуванням.Науковий вісник Національного університету біоресурсів і природокористування України. Серія: Філологічні науки. Вип.281. Київ, 2018. С.240-247.

6. Якушко К. Г., Мірошник В. О., Дудник А. О., Лисенко В. П. Англійська мова для майбутніх фрахівців 3 автоматизації АПК: навч. посіб. Київ: Експодрук, 2018. 351 с.

\section{References}

1. Shynkaruk, V.D., Kharchenko, S.V. (2017). Metodyka lingvistychnoho opysuvannia nazv zelenykh nasadzhen [The method of linguistic description of the titles of green plantations]. Naukovyi visnyk Natsionalnoho universytetu bioresursiv i pryrodokorustuvannia Ukrainy. Seriia: Filolohichni nauky. (Scientific Herald of National University of Life and Environmental Sciences of Ukraine. Series: Philological Sciences). Issue. 276, 71-78

2. Yakushko, K. H. (2017). Rol terminosystemy tekstu «Vehicle Parts» $\mathrm{u}$ formuvanni inshomovnoii kultyry spilkuvannia maibutnioho agroinzhenera [The role of the terminology system of the text in the formation of a foreign language communication culture of the future agroengineer]. Naukovyi visnyk Natsionalnoho universytetu bioresursiv i pryrodokorustuvannia Ukrainy. Seriia: Filolohichni nauky. (Scientific Herald of National University of Life and Environmental Sciences of Ukraine. Series: Philological Sciences). Issue 276. 86-94

3.Yakushko, K. H. (2018). Terminolohichnyi analiz inshomovnoho tekstovoho material pershoho modulia iz sfery avtomatyky [Terminological analysis of foreign language text material of the first module from the sphere of automation]. Molodyi Vchenyi (Young Scientist). Issue 8 (60). 111-116.

4. Yakushko, K.H. (2018). Leksychnostrukturni osoblyvosti inshomovnoho tekstovoho materialu druhoho modulu iz sfery avtomatyky [Lexical-structural features of foreign language text material of the second module from the sphere of automation]. Molodyi Vchenyi (Young Scientist). Issue 9 (61). 128-131.

5.Yakushko, K.H., Berezova, L.V. (2018) Praktychna spriamovanist terminolohichnoho analizu poniattia «switch» na zaniatti z anhliiskoi movy za 
profesiinym spriamuvanniam [The practical orientation of the terminological analysis of the concept «switch» on the lessons of professionally oriented English]. Naukovyi visnyk Natsionalnoho universytetu bioresursiv i pryrodokorustuvannia Ukrainy. Seriia: Filolohichni nauky. (Scientific Herald of National University of Life and
Environmental Sciences of Ukraine. Series: Philological Sciences). Issue 281. $240-247$.

6. Yakushko, K.H., Miroshnyk, V.O., Dudnyk A.O., Lysenko, V.P. (2018). Anhlijska mova dlia maibutnikh fakhivtsiv z avtomatyzatsii APK [English for the future specialists in agricultural automation]. 351.

\title{
ПОПЕРЕДНІ ЕТАПИ ТЕРМІНОЛОГІЧНОЇ РОБОТИ 3 ПОНЯТТЯМИ АВТОМАТИКИ
}

\author{
К. Г. Якушко
}

Анотація. Актуальність дослідження - у описі практики здійснення мовознавчих студій на практичних заняттях з англійської мови за профресійним спрямуванням. Основні висновки: розвиток міжпредметних зв'язків фрілології $з$ технічними дисциплінами $\epsilon$ важливою передумовою розвитку професійної мобільності кожного майбутнього інженера-автоматника. Роботу 3 терміносистемою автоматики доцільно здійснювати за певним алгоритмом, периі стадії якого (попереднє виявлення незнайомих понять фрахових текстів; інвентаризація наявних лексичних одиниць, пов'язана з конкретизацією термінів саме відповідної галузі знань та виявлення найбільш поширених у практиці стійких фахових термінів-словосполучень) є підгрунтям для переходу на більш відповідальні комунікативно-спрямовані стадії роботи з терміносистемою. Перспективою дослідження $\epsilon$ опис подальших стадій роботи з термінологічними одиницями автоматизації на практичних заняттях з англійської мови за профресійним спрямуванням: звуження кола для практичного використання за вибором студентів; підбір найбільш вдалих словосполучень після ознайомлення 3 допоміжними комунікативними таблииями вияву різних комунікативних намірів; закріплення отриманих мовознавчих знань у ділових іграх та діалогах-дуелях.

Ключові слова: терміни автоматики, алгоритм термінологічної роботи, практичні лінгвістичні студії, попередні стадії термінологічної роботи, англійська мова за професійним спрямуванням, майбутній інженер-автоматник 